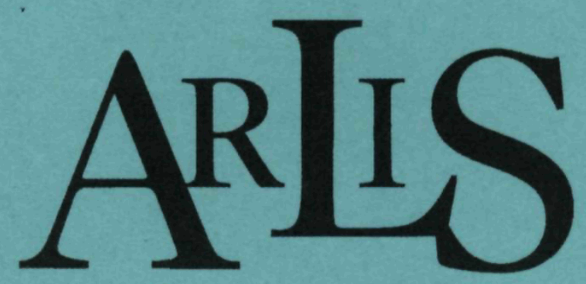

UK \& Ireland

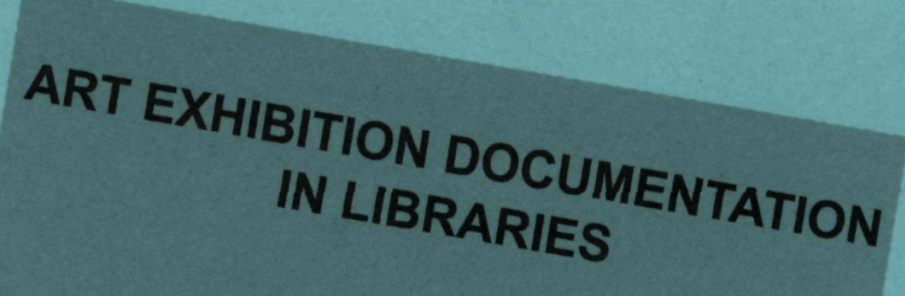

Cataloguing Guidelines

\title{
Artists' books
}

a cataloguers' manual

\section{ORIDEER YOURS TIODAN!}

Both books are available through all usual library book suppliers. Individual copies can also be purchased through Amazon. 